\section{Response of Four Strawberry Cultivars to Clopyralid Applied during Fruiting Stage}

\author{
Clinton J. Hunnicutt ${ }^{1}$, Andrew W. MacRae ${ }^{2}$, and \\ Vance M. Whitaker ${ }^{3,4}$
}

\begin{abstract}
ADDITIONAL INDEX WORDs. growth regulator, herbicide tolerance
SUMmARY. With the reduction in the availability of methyl bromide as a soil fumigant for Florida strawberry (Fragaria $\times$ ananassa) culture, annual broadleaf weeds are expected to become increasingly troublesome to control. Recent studies show that along with the new fumigant systems, separate but complementary herbicide applications throughout the growing season will also be a necessity for acceptable weed control. The purpose of the study reported herein was to evaluate the impacts of multiple rates of the herbicide clopyralid on the growth and fruit production of four annual strawberry cultivars. Two greenhouse trials were conducted, evaluating the application of varying rates of clopyralid as a directed spray to well-established, mature plants of 'Strawberry Festival', 'Florida Radiance', 'Treasure', and Winterstar ${ }^{\mathrm{TM}}$ 'FL 05-107'. Leaf production, leaf malformation, and marketable yield were evaluated to determine negative effects because of the physiological herbicidal effects, phytotoxic herbicidal effects, or both of clopyralid. Results from these studies showed that when clopyralid was applied at the maximum labeled rate of $3 \mathrm{oz} / \mathrm{acre}$, less than 12\% leaf malformation was observed among all cultivars, and marketable yield exhibited a linear increase as the rate of clopyralid increased, possibly due to a reduction in canopy coverage leading to more effective pollination.
\end{abstract}

$\mathrm{D}$ uring Winter 2010-11, strawberries were planted in westcentral Florida on $\approx 9900$ acres, with an estimated value of $\$ 366$ million [U.S. Department of Agriculture (USDA), 2011]. On an annual basis, this production accounts for a large portion of the domestically produced winter crop, and $\approx 10 \%$ to $15 \%$ of the total U.S. production. As of $2007, \approx 90 \%$ of Florida strawberry production occurred within Hillsborough County, with the remainder of the crop scattered throughout west-central Florida (USDA, 2007). Advancements in breeding of short-day cultivars have given Florida producers a unique market advantage to provide higher volumes than any other domestic producer during the winter (Jones et al., 2003). This ability enables Florida producers to receive premium prices for strawberries, making strawberries an economically

We thank Nathan Boyd for multiple reviews of this manuscript.

${ }^{1}$ Syngenta Seeds, 10290 Greenway Road, Naples, FL 34114

${ }^{2}$ Dow AgroSciences Canada, 127-337 Warde Avenue, Winnipeg, MB, Canada R2N 0A7

${ }^{3}$ Gulf Coast Research and Education Center, IFAS, University of Florida, 14625 County Road 672, Wimauma, FL 33598

${ }^{4}$ Corresponding author. E-mail: vwhitaker@ufl.edu. important crop to the state (Santos et al., 2007).

Weed control in annual strawberry is concentrated in two areas: the soil beneath the mulch-covered beds and the bare ground area between adjacent mulch-covered beds also referred to as the row-middle (Mossler and Nesheim, 2004). Soil fumigants in combination with herbicides are the two most common methods of weed control in commercial strawberry production (Fennimore et al., $2003)$. Weed pressure within the planting bed comes from weeds in the planting holes, with the exception of nutsedge (Cyperus sp.), which can puncture and grow through the plastic. Weeds growing in the planting holes typically begin to germinate within 3 to 5 weeks after planting (WAP) and compete with the crop for light, nutrients, and water (Gilreath and Santos, 2005 ). Although many annual weeds can be controlled with fumigation, dormant hard-seeded annual weeds such as carolina geranium (Geranium carolinianum), black medic (Medicago lupulina), and cutleaf eveningprimrose (Oenothera laciniata) can survive fumigant treatment and become mid- to late-season problems (Mossler, 2010; Stall, 2008).

Clopyralid has previously been shown to be a potential candidate for postemergent (POST) broadleaf weed control in both perennial mattedrow production as well as annual plasticulture production of strawberries (Clay and Andrews, 1984; Figueroa and Doohan, 2006; McMurry et al., 1996). In 2006, Figueroa and Doohan conducted trials with clopyralid application rates ranging from 25 to $400 \mathrm{~g} \cdot \mathrm{ha}^{-1}$ applied as a postharvest spray in a perennial strawberry production system. Common groundsel (Senecio vulgaris) control of $82 \%$ was achieved when clopyralid was applied at $200 \mathrm{~g} \cdot \mathrm{ha}^{-1}$ without adverse effects to strawberry plant growth. Although strawberry foliage growth was unaffected, a significant yield increase was reported at $200 \mathrm{~g} \cdot \mathrm{ha}^{-1}$; however, it was speculated that this increase occurred because of seedling competition within the hand-weeded plots. At the maximum application rate of $400 \mathrm{~g} \cdot \mathrm{ha}^{-1}$, there was evidence of a significant reduction in strawberry yield as well as crop canopy (Figueroa and Doohan, 2006).

A study conducted by McMurry et al. (1996) investigated the effects of an early season application of clopyralid on actively growing annual strawberries grown in a plasticulture cropping system. Ninety percent control of vetch (Vicia sp.) was achieved 4 weeks after treatment (WAT) with clopyralid rates from 140 to $200 \mathrm{~g} \cdot \mathrm{ha}^{-1}$, whereas clopyralid at $70 \mathrm{~g} \cdot \mathrm{ha}^{-1}$ provided only $62 \%$ control 4 WAT. Regardless of rate, $100 \%$ control of vetch was achieved 8 WAT. A rate response was observed for control of black medic with an increase in weed control as the rate of clopyralid increased. Clopyralid at 70, 140, and $280 \mathrm{~g} \cdot \mathrm{ha}^{-1}$

\begin{tabular}{llll}
\hline $\begin{array}{l}\text { Units } \\
\begin{array}{l}\text { To convert U.S. to SI, } \\
\text { multiply by }\end{array}\end{array}$ & U.S. unit & SI unit & $\begin{array}{l}\text { To convert SI to U.S., } \\
\text { multiply by }\end{array}$ \\
\hline 0.4047 & acre $(\mathrm{s})$ & $\mathrm{ha}$ & 2.4711 \\
3.7854 & $\mathrm{gal}$ & $\mathrm{L}$ & 0.2642 \\
70.0532 & $\mathrm{oz} / \mathrm{acre}$ & $\mathrm{g} \cdot \mathrm{ha}^{-1}$ & 0.0143 \\
6.8948 & $\mathrm{psi}$ & $\mathrm{kPa}$ & 0.1450
\end{tabular}


provided $49 \%, 63 \%$, and $83 \%$ control of black medic 4 WAT, respectively. McMurry et al. (1996) hypothesized that the control of black medic was related directly to spray coverage. It was noted that black medic plants that survived were small and generally located under the canopy of strawberry plants, ultimately leading to less than $100 \%$ control. Regardless of season, growth stage, or application rate, crop injury was reportedly less than $6 \%$ and confined to higher clopyralid rates (McMurry et al., 1996).

As strawberry producers transition from methyl bromide to alternative fumigants, the need for alternative weed management products and practices will become important to maintain the standard of quality expected of the industry. Although strawberry has been shown to exhibit acceptable tolerance to clopyralid, differing levels of tolerance among cultivars have not been studied. Differing levels of tolerance to certain herbicides between cultivars is evident (Baker and Peeper, 1990; Lemerle and Hinkley, 1991; Monks et al., 1992). Lemerle and Hinkley (1991) showed that canola (Brassica napus and Brassica campestris) cultivars differ in their level of tolerance to clopyralid. The canola cultivar Hyola 30 was most sensitive, with the application of clopyralid resulting in a yield reduction of $16 \%$ to $19 \%$. Greater differences were reported by Monks et al. (1992) who examined the tolerance of multiple sweet corn (Zea mays) cultivars to applications of nicosulfuron and primisulfuron. When nicosulfuron and primsulfuron were applied at 35 and $42 \mathrm{~g} \cdot \mathrm{ha}^{-1}$, injury was reported at $98 \%$ and $97 \%$, respectively, for the sweet corn cultivar Merit. Other cultivars such as Incredible, Landmark, Silver Queen, and Sweetie 76 were deemed tolerant, with less than $16 \%$ injury reported (Monks et al., 1992).

The purpose of this study was to examine the extent of injury to the major strawberry cultivars grown in Florida from a POST application of clopyralid to explore the potential of this herbicide in Florida strawberry production.

\section{Materials and methods}

Two identical greenhouse trials were conducted during Winter 201011 at the University of Florida/IFAS Gulf Coast Research and Education Center in Wimauma, FL. Rooted transplants of 'Strawberry Festival' (hereafter referred to as 'Festival'), 'Florida Radiance' (hereafter referred to as 'Radiance'), 'Treasure', and Win$\operatorname{terstar}^{\mathrm{TM}}$ 'FL 05-107' [U.S. Patent Pending (hereafter referred to as Winterstar $^{\mathrm{TM}}$ )] were planted into black l-gal polyethylene pots filled with Fafard \#2 potting media (Conrad Fafard, Agawam, MA). Strawberry plants for the first trial were potted on 25 Oct., with the remaining potted on $12 \mathrm{Nov}$. for the second trial. All plants were watered daily or as needed to maintain adequate media moisture.

Treatments consisted of a spray application of clopyralid at the rate of $0,3,6,9$, and $12 \mathrm{oz} /$ acre. Herbicide treatments were applied with a carbon dioxide $\left(\mathrm{CO}_{2}\right)$-pressurized backpack sprayer calibrated to deliver $30 \mathrm{gal} /$ acre at 30 psi using $11004 \mathrm{XR}$ nozzles (TeeJet Technologies, Springfield, IL). Treatment applications for the two trials were separated by $\mathrm{l} d$ with the first trial being treated on $12 \mathrm{Jan}$., 11 WAP, and the second on 13 Jan. (9 WAP). Following treatment application, irrigation water was directed toward the base of the plant and away from foliage once each day. Each treatment included four plants per cultivar and was replicated five times, for a total of 400 plants per trial. All treatments were arranged in a randomized complete block design.

Initial leaf counts were taken on 11 and 12 Jan. for the first and second trial, respectively. Strawberry fruits were harvested from each plant according to industry standard for fresh market fruit with a minimum of $95 \%$ color, and graded by recording the number and weight of marketable and malformed fruit. Harvest continued for 5 weeks with two harvests per week. Following the final harvest at 5 WAT, leaf counts were taken by recording the total numbers of leaves per plant in addition to the number of malformed leaves per plant. Final leaf count, along with the initial count, were used to calculate the number of new leaves formed per plant during the 5 -week period from the time of application till final harvest, including percentage of new leaves that were malformed.

Leaf count data were analyzed using generalized linear mixed models in the PROC GLIMMIX procedure in SAS (version 9.2; SAS Institute, Cary, NC) to investigate the effect of herbicide rate and strawberry cultivar on new leaf production, percentage of malformed leaves, and marketable yield. The leaf malformation data are presented as the percentage of new leaves that become malformed during the 5-week postapplication period. Yield data are presented as the number of marketable fruit per plant. Cultivar, clopyralid rate, and cultivar by rate were treated as fixed effects while trial by replication was treated as the random effect in the model. The SLICE function was used to analyze the effect of rate at each level of cultivar, and treatment means were compared using Fisher's protected least significant difference test at $\alpha=$ 0.05 . Curve fitting was performed using Sigmaplot (version 12.0; Systat Software, San Jose, CA).

\section{Results}

New leaf data as well as leaf malformation data were combined across trials and are presented by cultivar in response to clopyralid rate. All leaf data were fitted using the treatment means and standard errors estimated from the generalized linear mixed model analysis to the quadratic equation $f=y 0+a x+b x^{2}$, where $f$ is the number of new leaves or percent of leaf malformation and $x$ represents the clopyralid rate.

For marketable yield, no cultivar by rate interactions were observed, and the data were therefore combined across trials and cultivars and presented as marketable fruit per plant in response to clopyralid rate. Data were then best fit using treatment means and standard errors estimated from the generalized linear mixed model analysis to the linear equation $f=\mathrm{y} 0+\mathrm{a} x$, where $f$ is the number of marketable fruit per plant and $x$ represents the clopyralid rate.

New Leaf formation. For each cultivar, treatment means for new leaves formed and clopyralid rate was fit to a quadratic equation with coefficient of determination $\left(r^{2}\right)$ values of $0.97,0.93,0.92$, and 0.65 for Winterstar $^{\mathrm{TM}}$, 'Treasure', 'Radiance', and 'Festival', respectively (Fig. 1). Clopyralid applied to 'Treasure' at 1.3 and $2.7 \mathrm{oz} /$ acre was estimated to decrease new leaf production $10 \%$ and $20 \%$, respectively. 'Radiance' was estimated to show a $10 \%$ and $20 \%$ reduction in new leaves at 1.6 and 3.7 $\mathrm{oz} / \mathrm{acre}$ of clopyralid, respectively. 
Winterstar ${ }^{\mathrm{TM}}$ ' showed a $10 \%$ estimated reduction in new leaves at $3.3 \mathrm{oz} / \mathrm{acre}$, whereas 'Festival' displayed an estimated $10 \%$ reduction at $4.9 \mathrm{oz} /$ acre of clopyralid. A $20 \%$ reduction in new leaves on 'Festival' was estimated at $8.6 \mathrm{oz} /$ acre. Since a biologically appropriate curve could not be fit to the Winterstar ${ }^{\mathrm{TM}}$ data, predictions outside the measured parameters were not performed, leading to a $20 \%$ reduction in new leaves of Winterstar ${ }^{\mathrm{TM}}$ estimated at greater than $12 \mathrm{oz} /$ acre of clopyralid.

LeAF MALFormation. For each cultivar, treatment means of percent malformed leaves and clopyralid rate were fit to a quadratic equation with $r^{2}$ values of $0.98,0.98,0.91$, and 0.89 for Winterstar ${ }^{\mathrm{TM}}$, 'Festival', 'Radiance', and 'Treasure', respectively (Fig. 2). A 10\% and 20\% level of leaf malformation was predicted for 'Festival' when clopyralid was applied at 2.9 and $5.9 \mathrm{oz} /$ acre, respectively. For 'Radiance' and 'Treasure', a 10\% level of leaf malformation was estimated at 4.8 and $7.2 \mathrm{~g} \cdot \mathrm{ha}^{-1}$, whereas $20 \%$ leaf malformation was predicted at 8.6 and $10.6 \mathrm{~g} \cdot \mathrm{ha}^{-1}$, respectively. Since a biologically appropriate curve could not be fit to the data, predictions outside of the measured parameters were not performed resulting in $10 \%$ and $20 \%$ leaf malformation estimated at greater than $12 \mathrm{~g} \cdot \mathrm{ha}^{-1}$ of clopyralid for Winterstar ${ }^{\mathrm{TM}}$.

Marketable Yield. Marketable yield data exhibited substantial variability between replications within trials as well as within cultivars. Therefore, no interactions between cultivars were observed and marketable yield data were pooled across all cultivars and both trials for analysis. The relationship between marketable yield and clopyralid rate was well described by a linear equation with an $r^{2}$ value of 0.96 (Fig. 3). The well-correlated linear relationship showed an increase in marketable strawberry yield (across all cultivars and both trials) as clopyralid rate increased. Overall marketable yield increased by an estimated $18 \%$ and $35 \%$ at 3 and $6 \mathrm{oz} /$ acre, respectively. Clopyralid applied at 9 and $12 \mathrm{oz} /$ acre was predicted to increase yield by $52 \%$ and $70 \%$, respectively.

\section{Discussion}

Significant cultivar by rate interactions for new and malformed leaves suggest differences in tolerance levels

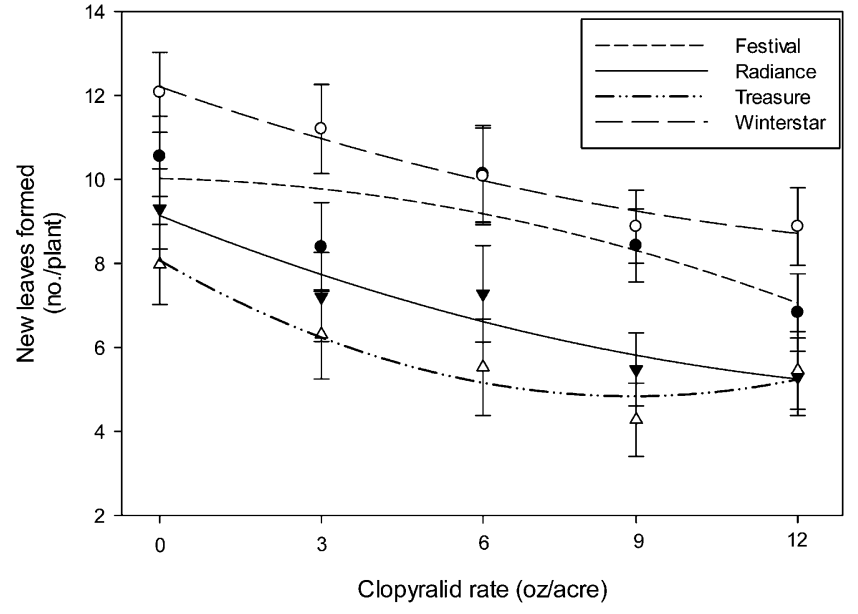

Fig. 1. Number of new leaves formed for four greenhouse-grown strawberry cultivars [Strawberry Festival (Festival), Florida Radiance (Radiance), Treasure, and Winterstar ${ }^{\mathrm{TM}}$ FL 05-107 (Winterstar)] in response to five rates of clopyralid ranging from 0 to $12 \mathrm{oz} /$ acre, 5 weeks after treatment. Data values represent mean $\pm \mathrm{SE}$. For each cultivar, the regression model is $f=y 0+a x+b x^{2}$ : Festival $(y 0=10.0203$, $a=-0.0004, b=-3.7524 \times 10^{-6}, x=$ rate, $\left.r^{2}=0.65\right)$, Radiance $(y 0=9.1408, a=$ $-0.0073, b=3.1351 \mathrm{E}-6, x=$ rate, $\left.v^{2}=0.92\right)$, Treasure $(y 0=8.0701, a=-0.0104$, $b=8.3601 \times 10^{-6}, x=$ rate, $\left.r^{2}=0.93\right)$, Winterstar $(y 0=12.2057, a=-0.0064, b=$ $2.629 \times 10^{-6}, x=$ rate, $\left.r^{2}=0.97\right) ; 1 \mathrm{oz} /$ acre $=70.0532 \mathrm{~g} \cdot \mathrm{ha}^{-1}$.

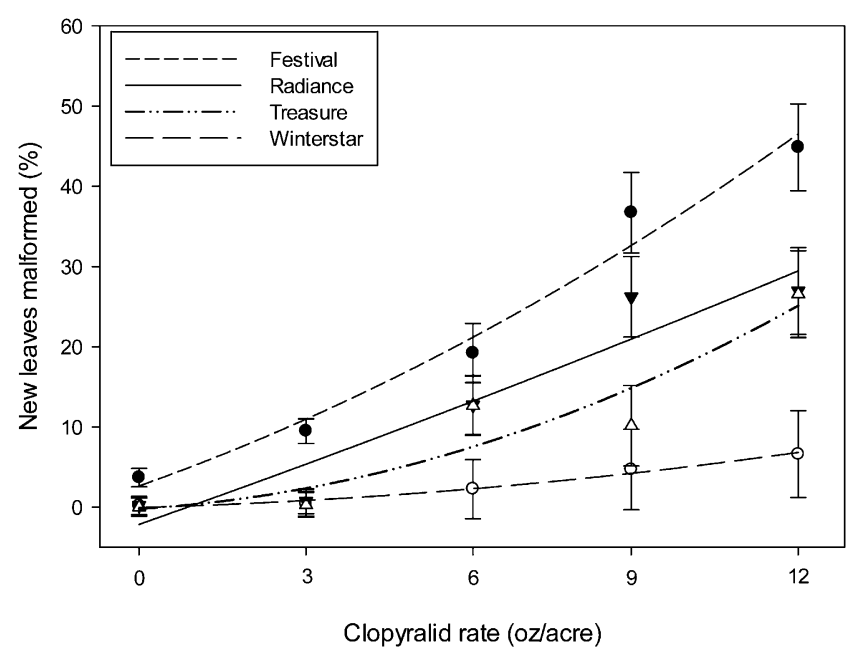

Fig. 2. Percentage of new leaf malformation for four greenhouse-grown strawberry cultivars [Strawberry Festival (Festival), Florida Radiance (Radiance), Treasure, and Winterstar ${ }^{\mathrm{TM}}$ FL 05-107 (Winterstar)] in response to five rates of clopyralid ranging from 0 to $12 \mathrm{oz} /$ acre, 5 weeks after treatment. Data values represent mean $\pm \mathrm{SE}$. For each cultivar, the regression model is $f=y 0+a x+b x^{2}$ : Festival $(y 0=2.6423$, $a=0.0346, b=2.0874 \times 10^{-5}, x=$ rate, $\left.v^{2}=0.98\right)$, Radiance $(y 0=-2.1521, a=$ $0.0345, b=3.6957 \times 10^{-6}, x=$ rate, $\left.r^{2}=0.91\right)$, Treasure $(y 0=-0.2106, a=$ $0.0059, b=2.8813 \times 10^{-5}, x=$ rate, $\left.r^{2}=0.89\right)$, Winterstar $(y 0=-0.0444, a=$ $0.0027, b=6.4724 \times 10^{-6}, x=$ rate, $\left.r^{2}=0.98\right) ; 1 \mathrm{oz} /$ acre $=70.0532 \mathrm{~g} \cdot \mathrm{ha}^{-1}$.

among the cultivars tested. Strawberry cultivars, even within a specific class (i.e., short-day), can vary in their response to environmental factors such as temperature and photoperiod (Darnell, 2003). These factors could contribute significantly to the differential expression of tolerance of these cultivars to clopyralid. Winterstar ${ }^{\mathrm{TM}}$ produced the highest number of new leaves while also expressing the lowest percentage of malformed new leaves, indicating a possible tolerance to clopyralid relative to the other cultivars.

The strong linear relationship observed between marketable yield 


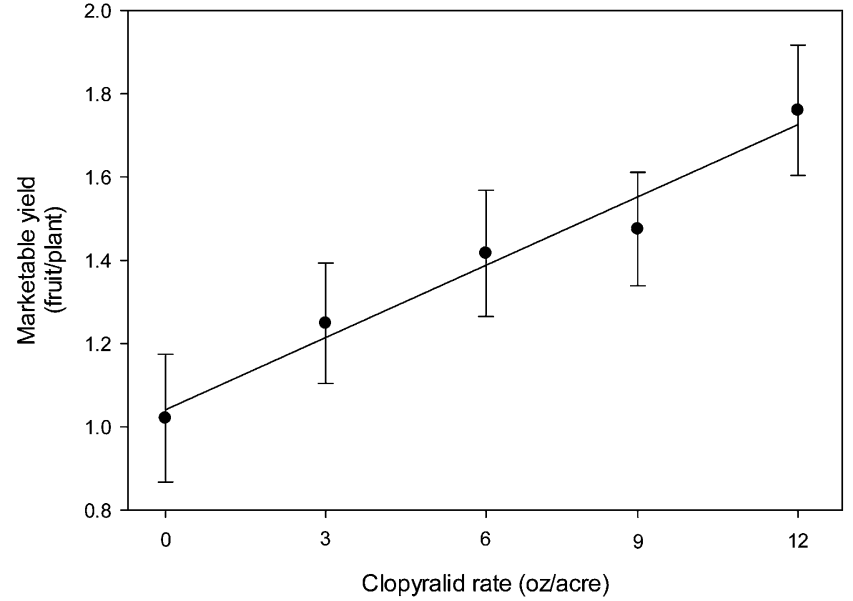

Fig. 3. Marketable yield of four greenhouse-grown strawberry cultivars in response to clopyralid rates ranging from 0 to $12 \mathrm{oz} /$ acre, expressed as the number of marketable fruit per plant. The regression equation represents data pooled across two replicated greenhouse trials and four strawberry cultivars. Data values represent mean $\pm \mathrm{SE}$. The regression model is $f=y 0+a x$, where $y 0=1.041, a=0.0008, x=$ rate, and $r^{2}=0.96 ; 1 \mathrm{oz} /$ acre $=70.0532 \mathrm{~g} \cdot \mathrm{ha}^{-1}$.

and clopyralid rate is thought to be directly related to inadequate pollination of strawberry flowers in the greenhouse, and indirectly related to clopyralid rate. In general, the primary means of pollination of strawberry flowers are wind and gravity (McCandless and Korvak, 2003). Fruit deformation and yield reduction can become problems in greenhousegrown strawberries when pollinators are not introduced (Kakutani et al., 1993). For this reason, honeybees (Apis mellifera) are one of the most common pollinators and recommended for greenhouse or protected culture of strawberries (Goodman and Oldroy, 1988; Hancock, 1999; Nye and Anderson, 1974). The potential impacts of poor pollination in these results cannot be ignored. It is possible that as leaf malformation increased, there was an overall reduction in canopy coverage resulting in more effective pollination of flowers from the small amount of air movement provided by greenhouse fans. It is not possible to completely rule out the potential confounding effects of pollination masking the actual effect of clopyralid on marketable yield. Therefore, field studies are needed to further examine the effect of clopyralid on marketable yield in a typical openfield cropping situation.

In comparison with previous literature, results from this study showed higher levels of leaf malformation at comparable rates. This variability between the expression of herbicide injury on plants grown in the greenhouse- and open-field-grown plants was recently investigated by Riemens et al. (2008). Riemens et al. (2008) showed that among the four species tested, all were more sensitive to applied glufosinate ammonium when grown in the greenhouse compared with the field-grown plants. Although glufosinate has a much different mode of action in comparison with clopyralid, Riemens et al. (2008) hypothesized this difference among field and greenhouse plants was a function of environmental conditions that differentially promoted the rates of plant growth. If this environment effect of the greenhouse was causing increased vegetative growth of the strawberry plants, it would help explain the increase in leaf malformation because of the overall increase in total leaf production.

Kloppenburg and Hall (1990) showed that in canada thistle (Cirsium arvense), the monoethanolamine salt formulation of clopyralid differed in the percentage of absorption and translocation under differing relative humidity $(\mathrm{RH})$ regimes. At $65 \% \mathrm{RH}$, carbon-14 $\left({ }^{14} \mathrm{C}\right)$ labeled clopyralid formulated as a monoethanolamine salt was shown to be absorbed and translocated at $80 \%$ and $55 \%$, respectively, of applied product, $72 \mathrm{~h}$ after treatment (HAT). When RH was decreased to $35 \%,{ }^{14} \mathrm{C}$-labeled clopyralid absorption and translocation was decreased to $60 \%$ and $45 \%$ of applied product 72 HAT, respectively. Findings from this study would suggest that clopyralid applied in a greenhouse situation, at higher RH in comparison with field settings, would have greater absorption and translocation and thus cause more injury to strawberry plants.

In conclusion, the loss of methyl bromide means that Florida strawberry growers must identify alternative weed management options. Several broadleaf weed species are not adequately controlled with currently registered fumigation and preemergent herbicide options in Florida, and clopyralid is the only herbicide registered for broadleaf weed control that can be applied posttransplant. Clopyralid currently has an EPA 24(c) special local need registration for use in Florida on strawberries with a $7 \mathrm{~d}$ preharvest interval (PHI), and further research is needed to determine whether a $3-4 \mathrm{~d}$ PHI will be possible. Previous research found that clopyralid was safe on strawberry within specific application rates. This study suggests that strawberry cultivars differ in their tolerance to POST applications of clopyralid. Symptoms increased with herbicide rate and included a reduction in the number of new leaves and production of malformed leaves. This study showed more severe plant injury at comparable rates to previous literature, which is likely due to the influence of the closed greenhouse environment. Future studies using clopyralid in open-field strawberry cropping situations should include multiple cultivars. Further research will be conducted to examine the impact of rate and application timing on weed efficacy and crop safety across a range of herbicide rates and plant cultivars.

\section{Literature cited}

Baker, T.A. and T.F. Peeper. 1990. Differential tolerance of winter wheat (Triticum aestivum) to cyanazine and triazinone herbicides. Weed Technol. 4:569-575.

Clay, D.V. and L. Andrews. 1984. The tolerance of strawberries to clopyralid: Effect of crop age, herbicide dose and application date. Asp. Appl. Biol. 8:151-158.

Darnell, R.L. 2003. Strawberry growth and development, p. 3-10. In: N.F. Childers (ed.). The strawberry: A book for growers, others. Dr. Norman F. Childers Publ., Gainesville, FL. 
Fennimore, S.A., M.J. Haar, and H.A. Ajwa. 2003. Weed control in strawberry provided by shank- and drip-applied methyl bromide alternative fumigants. HortScience 38:55-61.

Figueroa, R.A. and D.J. Doohan. 2006. Selectivity and efficacy of clopyralid on strawberry (Fragaria x ananassa). Weed Technol. 20:101-103.

Gilreath, J.P. and B.M. Santos. 2005. Weed management with oxyfluorfen and napropamide in mulched strawberry. Weed Technol. 19:325-328.

Goodman, R.D. and B.P. Oldroy. 1988. Honeybee pollination of strawberries (Fragaria $\mathrm{x}$ ananassa Duchesne). Austral. J. Exp. Agr. 28:435-438.

Hancock, J.F. 1999. Strawberries. CABI Publ., Cambridge, MA.

Jones, R.L., M.L. Duryea, and B.J. Treat. 2003. New plants for Florida: Introduction. 18 Apr. 2012. <http://edis.ifas. ufl.edu/ag205>.

Kakutani, T., T. Inoue, T. Tezuka, and Y. Maeta. 1993. Pollination of strawberry by the stingless bee (Trigona minangkabau), and the honey bee (Apis mellifera): An experimental study of fertilization efficiency. Popul. Ecol. 35:95-111.
Kloppenburg, D.J. and J.C. Hall. 1990. Effects of formulation and environment on absorption and translocation of clopyralid in Cirsium arvense (L.) Scop. and Polygonum convolvulus L. Weed Res. 30:9-20.

Lemerle, D. and R.B. Hinkley. 1991. Tolerances of canola, field pea, lupin and faba bean cultivars to herbicides. Austral. J. Exp. Agr. 31:379-386.

McCandless, L. and M. Korvak. 2003. Honey bees deliver beneficial fungi to strawberries, increasing yield, p. 3-10. In: N.F. Childers (ed.). The strawberry: A book for growers, others. Dr. Norman F. Childers Publ., Gainesville, FL.

McMurry, G.L., D.W. Monks, and R.B. Leidy. 1996. Clopyralid use in strawberries (Fragaria x ananassa) grown on plastic mulch. Weed Sci. 44:350-354.

Monks, D.W., C.A. Mullins, and K.E. Johnson. 1992. Response of sweet corn (Zea mays) to nicosulfuron and primsulfuron. Weed Technol. 6:280-283.

Mossler, M.A. 2010. Florida crop/pest management profiles: Strawberry. 28 Mar. 2012. <http://edis.ifas.ufl.edu/ pi037>.

Mossler, M.A. and O.N. Nesheim. 2004. Strawberry pest management strategic plan (PMSP). 22 Mar. 2012. <http:// edis.ifas.ufl.edu/pdffiles/PI/PI06300. pdf $>$.

Nye, W.P. and J.L. Anderson. 1974. Insect pollinators frequenting strawberry blossoms and the effect of honey bees on yield and fruit quality. J. Amer. Soc. Hort. Sci. 99:40-44.

Riemens, M.M., T. Dueck, and C. Kempenaar. 2008. Predicting sublethal effects of herbicides on terrestrial non-crop plant species in the field from greenhouse data. Environ. Pollut. 155:141-149.

Santos, B.M., C.K. Chandler, S.M. Olson, and T.W. Olczyk. 2007. Strawberry cultivar evaluations in Florida: 2006-07 Season. 18 Apr. 2012. $<$ http://edis.ifas.ufl.edu/hs374>.

Stall, W.M. 2008. Weed control in strawberry. 28 Mar. 2012. <http://edis.ifas.ufl. $\mathrm{edu} / \mathrm{wg} 037>$.

U.S. Department of Agriculture. 2007. Census of agriculture. 18 Apr. 2012. <http://www.agcensus.usda.gov/index. php>.

U.S. Department of Agriculture. 2011. USDA/NASS QuickStats ad-hoc query tool. 18 Apr. 2012. <http://quickstats. nass.usda.gov/results/0DC6653795EE-3EFA-8ABA-58CA754115Cl>. 